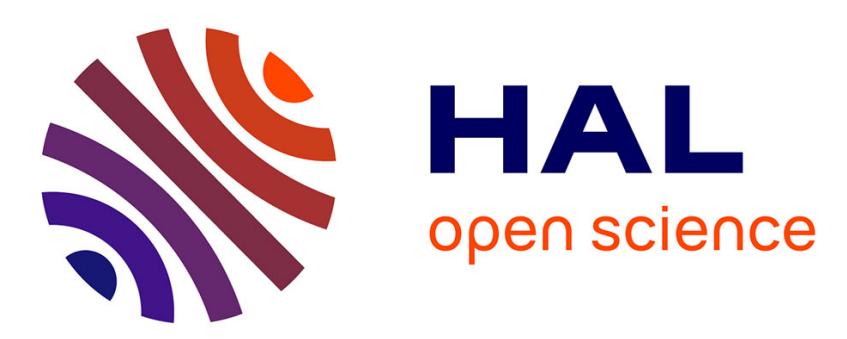

\title{
THIN FILM OF CERAMIC OXIDES BY MODIFIED CVD
}

J. Deschanvres, F. Cellier, G. Delabouglise, M. Labeau, M. Langlet, J. Joubert

\section{To cite this version:}

J. Deschanvres, F. Cellier, G. Delabouglise, M. Labeau, M. Langlet, et al.. THIN FILM OF CERAMIC OXIDES BY MODIFIED CVD. Journal de Physique Colloques, 1989, 50 (C5), pp.C5-695-C5-705. 10.1051/jphyscol:1989582 . jpa-00229615

\section{HAL Id: jpa-00229615 https://hal.science/jpa-00229615}

Submitted on 1 Jan 1989

HAL is a multi-disciplinary open access archive for the deposit and dissemination of scientific research documents, whether they are published or not. The documents may come from teaching and research institutions in France or abroad, or from public or private research centers.
L'archive ouverte pluridisciplinaire HAL, est destinée au dépôt et à la diffusion de documents scientifiques de niveau recherche, publiés ou non, émanant des établissements d'enseignement et de recherche français ou étrangers, des laboratoires publics ou privés. 
THIN FILM OF CERAMIC OXIDES BY MODIFIED CVD

\author{
J.I. DESChanVRES, F. CELlier, G. DELABOUglise, M. LABEAU, M. LANGLET \\ and J.C. JOUBERT \\ Institut National Polytechnique de Grenoble, Ecole Nationale \\ Supérieure de Physique de Grenoble, LMGP CNRS UA-1109, Domaine \\ Universitaire, $B P .46, F-38402$ st Martin d'Hères, France
}

Résumé : Nous décrivons un procédé de dépôt utilisant la pyrolyse d'un aérosol généré par ultrasons (procédé Pyrosol). La réaction chimique sur le substrat chauffé est de type CVD.

Nous avons étudié les conditions expérimentales de dépôt de zircone stabilisée à l'oxyde d'Yttrium, en vue de la réalisation de microcapteurs de gaz. Nous obtenons directement la phase cubique de la zircone stabilisée. Comme application en tant que média pour l'enregistrement magnéto-optique nous avons obtenu des couches de $\mathrm{Y}_{3} \mathrm{Fe}_{5} \mathrm{O}_{12}$ non orientées pour des dépôts sur quartz et des couches épitaxiées pour des dépôts sur des substrats monocristallins de GGG.

Abstract : We describe a deposition process which uses the pyrolysis of an aerosol produced by ultrasonic spraying (Pyrosol process). The chemical reaction on the heated substrate corresponds to CVD. Experimental deposition conditions of yttria stabilized zirconia have been studied with the aim of realizing microionic gas sensors. We obtain directly the stabilized cubic phase. For magneto-optical information storage or magneto-optical display devices we have deposited $\mathrm{Y}_{3} \mathrm{Fe}_{5} \mathrm{O}_{12}$ garnet thin films. Good quality thin layers were obtained, not textured on quartz substrates and epitaxialy grown on GGG substrates.

\title{
1. INTRODUCTION
}

Reactive chemical spraying offers advantages for mass production of thin film coatings. In this process the reactants are carried in the form of aerosol instead of gas phase. Large surfaces can be coated without protection against air at a relatively low temperature below $500^{\circ} \mathrm{C}$.

In this paper we describe a process that uses ultrasonic spraying to produce metal, metal oxide and sulfide thin films. This method, namely the Pyrosol process, is patented in France and others countries by J. Spitz and J.C. Viguie (1).

We describe also two examples for metal oxide coatings obtained in our Laboratory with this method : Y stabilized zirconia for gas sensor and $\mathrm{Y}_{3} \mathrm{Fe}_{5} \mathrm{O}_{12}$ garnet for magneto-optical information storage. 


\section{PYROSOL PROCESS}

\section{2-1 Principle}

The process is based on the pyrolysis on a heated substrate of an aerosol produced by an ultrasonic atomizing system.

If an ultrasonic beam is focused close to the surface of a liquid, the effects of cavitation within the liquid and of the vibrations on its surface produce an aerosol made with very fine droplets (fig. 1a). The mean diameter of the droplets is closely related to ultrasonic frequency $f$, liquid density $\rho$ and liquid surface tension $\sigma$ (2)

$d=k\left(\frac{8 \pi \sigma}{\rho f^{2}}\right)^{1 / 3} \quad(k=$ constant $)$

with a very narrow dispersion. At $800 \mathrm{kH}_{\mathrm{z}}$, for instance, the droplet size of methanol is between 4 and $6 \mu \mathrm{m}$.

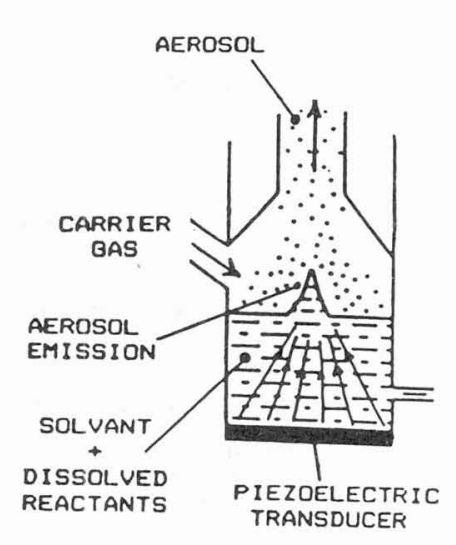

(a)

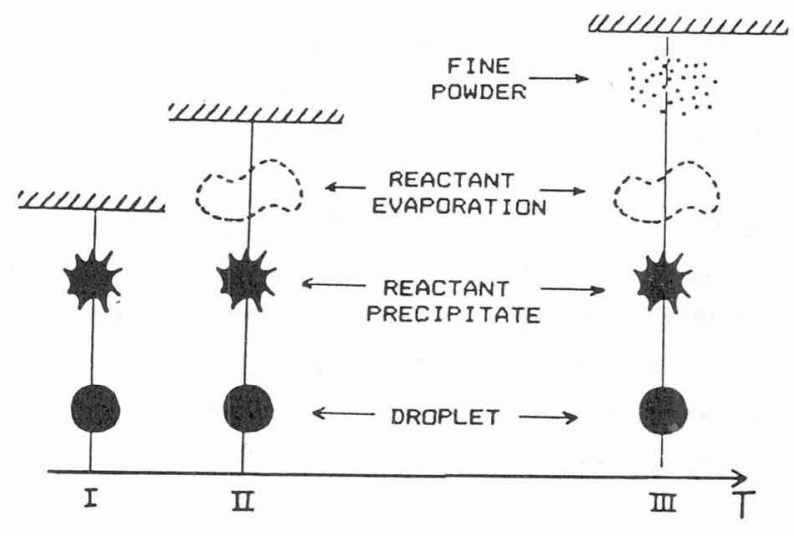

(b)

Fig. 1 - (a) aerosol production by ultrasonic atomizing system (b) - chemical reaction near the substrate as a function of temperature

The liquid is a solution containing the reactants of the materials to be deposited. These reactants can be metal organic compounds (acetylacetonates, alcoholates,...) or mineral compounds (metal halides, acetates,...). The choice of the reactant is determined according to the need of a high vapour pressure at low temperature, in order to increase the reaction kinetics on the substrate. Coatings of mixed oxides can be also obtained with a solution containing a mixture of several precursors in an appropriate solvent. In that case, complex ions can be formed in the liquid leading to deposition features different from those obtained with separate solutions.

The aerosol is conveyed by a carrier gas close to the heated substrate. In most cases this gas is purified air for oxide coatings, argon or nitrogen in some cases with a few per cent of hydrogen. when a slightly reducing atmosphere is required (metal coatings for instance). 
The nature of the chemical reaction near the substrate determines whether or not the process can be classified as chemical vapor deposition (CVD). The process nature varies with the temperature and droplet size, and is shown schematically in fig. 2b. Process II corresponds with CVD deposition where a heterogeneous surface reaction occurres. When the droplets approach the substrate, the solvent evaporates and the solid precipitate vapourizes or sublimes. The vapours diffuse to the substrate leading to heterogeneous reaction. Processes I and III do not correspond with CVD reaction and give inferior coatings. Thanks to the very narrow droplet spectrum of aerosol, the same deposition conditions apply for nearly all droplets of the aerosol. Thus the choice of process II conditions leads to a good quality of the films.

\section{2-2 Pyrosol process equipment}

Several different reactors have been perfected in the Laboratory. All of them use aerosol source, gas carriage, substrate heater and exhaust system. They differ from one another in geometry : the aerosol is conveyed in a direction parallel or perpendicular to the horizontal or vertical surface of the substrate. Each geometry has its own features which vary with the temperature, the gas flow, the concentration of reactants and the kind of deposited material. These features include : thickness homogeneity, coating microstructure and preferential orientation.

Figure 2 shows a reactor where aerosol is conveyed vertically and in a direction perpendicular to the horizontal substrate heated with RF. The diameter of the substrate is about $50 \mathrm{~mm}$.

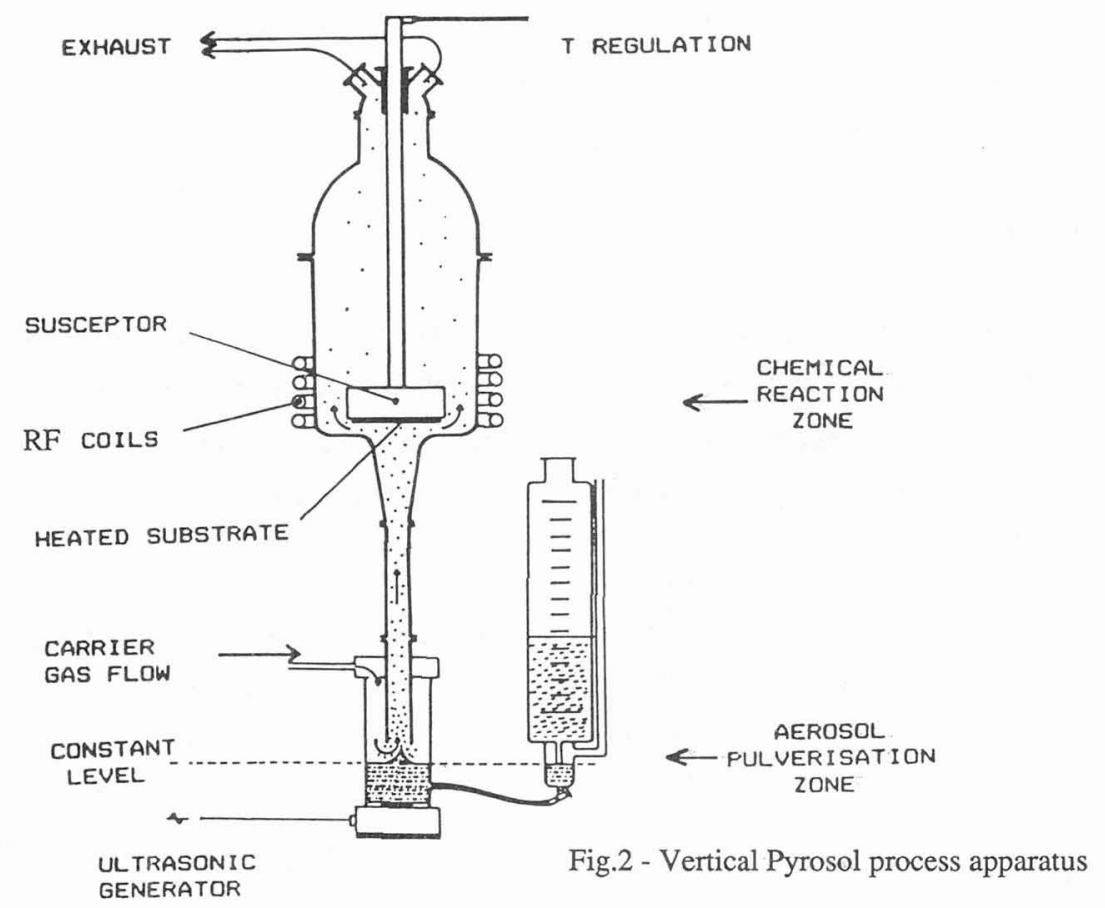

\section{2-3 Applications}

Most of the coatings obtained in the Laboratory with the pyrosol process are collected in table I. A large part of them are oxides, but some metals and sulfides have been deposited. Different kinds of substrates were used : glass, silicon, silica, $\mathrm{Al}_{2} \mathrm{O}_{3}$, etc... 
Table I - Coatings obtained by pyrosol process in the Laboratory.

\section{Metals}

Palladium,platinum electrodes

\section{Oxides}

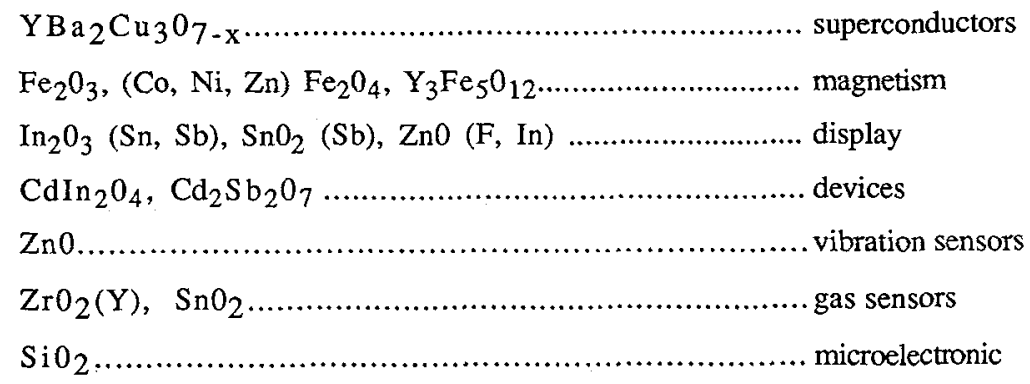

\section{Sulfides}

$\mathrm{ZnS}, \quad(\mathrm{Cd}, \mathrm{Zn}) \mathrm{S}$ electroluminescence

\section{YTTRIA-STABILIZED ZIRCONIA}

Doped oxides having the fluorite-type, fcc structure such as yttria-stabilized zirconia (YSZ) are well known as oxygen-ion conducting solid electrolytes. This cubic structure is fully stabilized when a $7 \% \mathrm{Y}_{2} \mathrm{O}_{3}$ molar ratio is introduced in the $\mathrm{ZrO}_{2}$ lattice (3) while the highest ionic conductance is obtained for a $10 \% \mathrm{Y}_{2} \mathrm{O}_{3}$ molar ratio (4). However, the value of the activation energy for oxygen transport remains very high and these materials must be used at high temperature. One way to decrease their working temperature is to increase the electrolyte conductance using coatings instead of monolithic ceramics. Besides the thin film technology can produce numerous small scale devices with reproducible properties. In view of the potential applications of these oxide films in gas sensors (5), we have investigated the Pyrosol process parameters for the deposition of $\mathrm{Y}_{2} \mathrm{O}_{3}$-doped $\mathrm{ZrO} 2$ coatings on various substrates. In this way, stable, nonporous, well crystallized and adherent films have been deposited and we present here the outstanding results.

\section{3-1 Experimental procedure}

The coating solution was prepared by dissolving metal organic compounds (Zirconium n-butyl and Yttrium acetylacetonate) in a butanol and acetylacetone mixture. The concentration was adjusted to $0.05 \mathrm{M}$ in order to get time-stable solutions. YSZ coating depositions were carried out on glass and alumina substrates with a vertical Pyrosol apparatus. Preliminary tests allowed us to optimize the deposition parameters with a $\mathrm{Y} / \mathrm{Zr}$ ratio in the coating solution varying from 0.1 to 0.3 and substrate temperature from $400^{\circ} \mathrm{C}$ to $600^{\circ} \mathrm{C}$. 
Crystal structure, grain size, thickness, phase composition and phase identification of the films have been studied by means of electron microscopy, X-ray microanalysis and diffraction techniques coupled with digital data storage and analysis systems.

\section{3-2 Results and discussion}

The quality of the YSZ films depends strongly on the coating temperature, both considering the microstructure and the $\mathrm{Y}_{2} \mathrm{O}_{3}$ content. Films were first deposited on glass substrates, $1.6 \mathrm{~mm}$ thick, between $400^{\circ} \mathrm{C}$ and $500^{\circ} \mathrm{C}$, with a $30 \%$ Ytrrium ratio in the coating solution.

Scanning Electron Microscope (SEM) examinations showed us that the higher the substrate temperature, the better the quality of the films which is due to an increase in grain size and crystallinity. It appears from X-ray microanalysis data that the doping ratio or $\mathrm{Y}_{2} \mathrm{O}_{3}$ content of the films varies from 10 to $20 \%$. Moreover, when coating was done up to $500^{\circ} \mathrm{C}$, transmission electron microscope (TEM) examinations revealed no apparent porosity between monocrystalline grains while films deposited down to $400^{\circ} \mathrm{C}$ appear to be less dense (Fig. 3). Electron diffraction patterns reveal an intensity increasing with the coating temperature, and X-ray diffraction patterns (fig. 4) confirm this observation. From X-ray diffraction data, it appears that on glassy substrates and coating temperatures high enough ( $\mathrm{T} \geq 450^{\circ} \mathrm{C}$ ), films crystallize in the cubic structure with a marked preferred orientation, the [200] direction being perpendicular to the surface of the film, while for lower temperature $\left(T=400^{\circ} \mathrm{C}\right)$ a rather amorphous structure is indicated by the absence of a distinguishable peak. Thus the importance of temperature as deposition parameter is clearly shown.
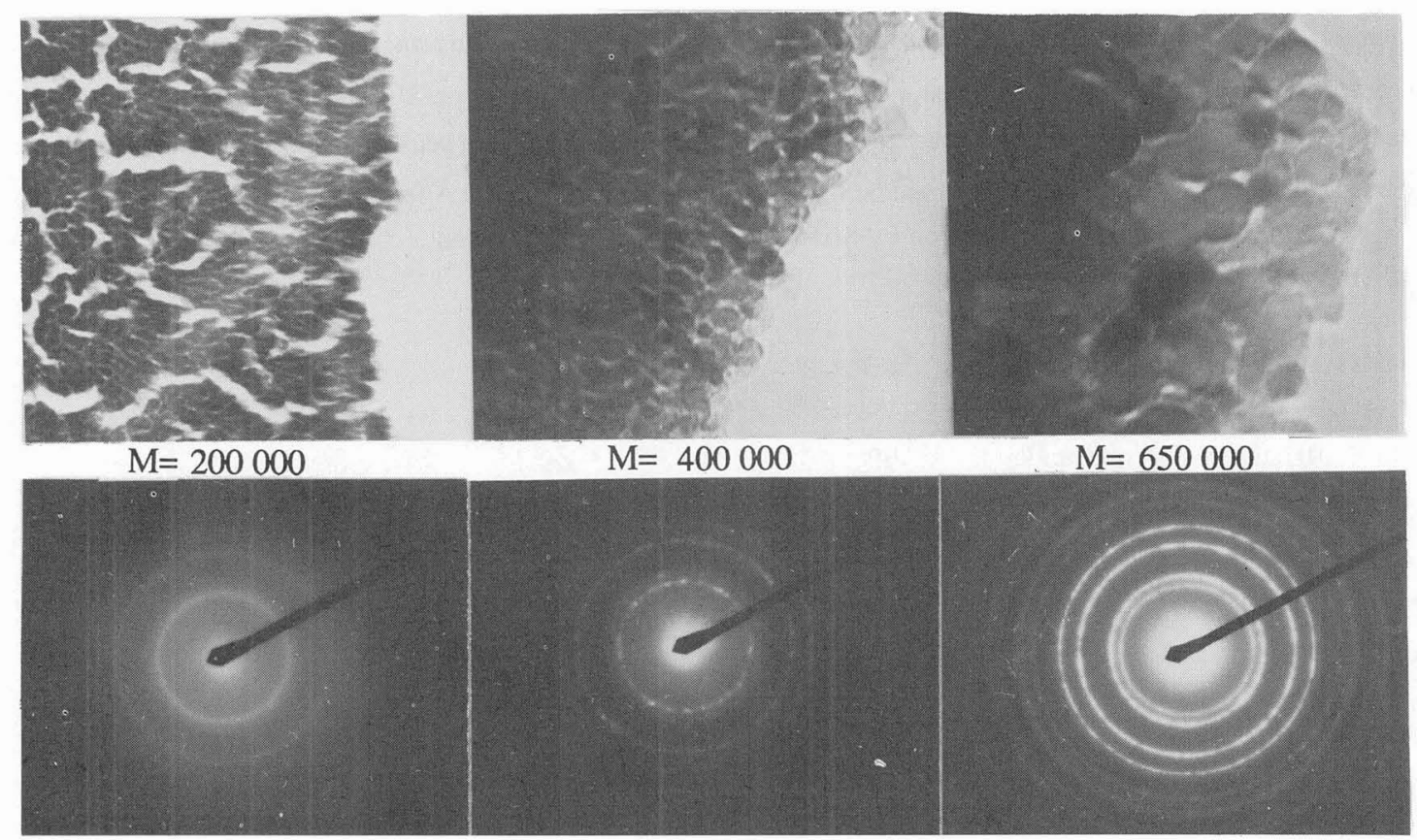

$M=400000$ $M=650000$
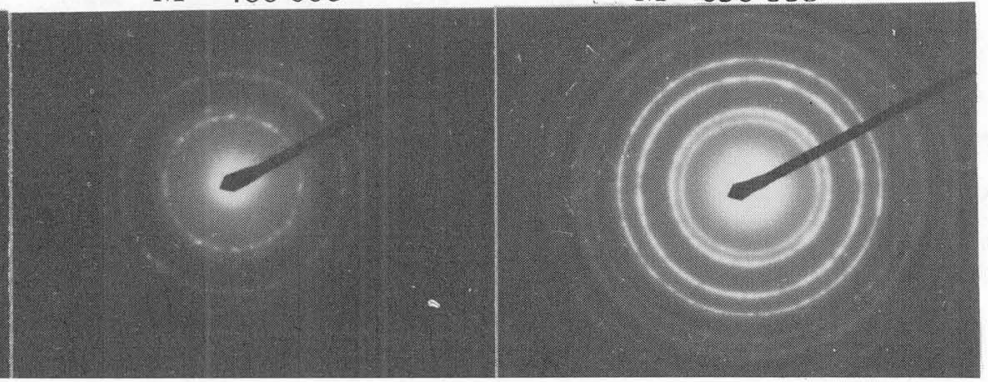

a

b

C

Fig. 3 : TEM micrographs and electron diffraction patterns of YSZ-coated glass substrates at various temperatures $\mathrm{a}: \mathrm{T}=400^{\circ} \mathrm{C} ; \mathrm{b}: \mathrm{T}=450^{\circ} \mathrm{C} ; \mathrm{c}: \mathrm{T}=500^{\circ} \mathrm{C} \cdot \mathrm{M}=\mathrm{TEM}$ micrographs magnification 
Fig. 4 : X-ray diffraction patterns at various temperatures

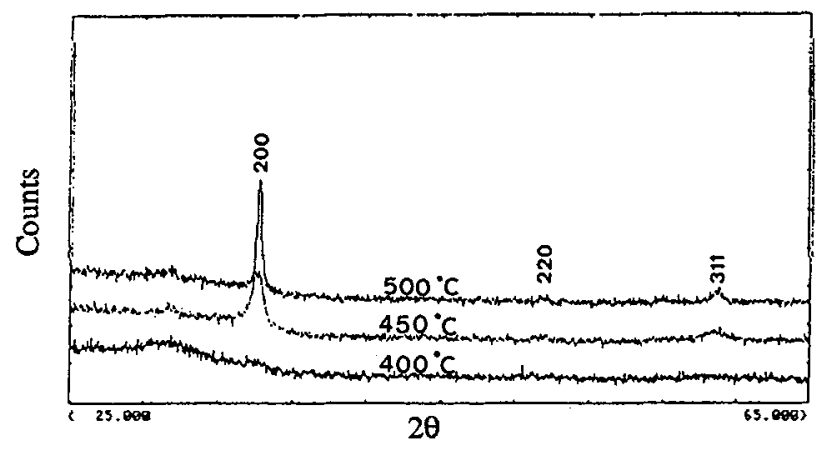

Due to the thermally limited properties of glass substrates $\left(\mathrm{Tg}=535^{\circ} \mathrm{C}\right)$, coatings were then carried out on alumina substrates, $0.6 \mathrm{~mm}$ thick, provided by Hoechst Ceramtec France. Besides, when considering the similar average expansion coefficient of zirconia $\left(7.10^{-6{ }^{\circ}} \mathrm{C}^{-1}\right)$ and alumina $\left(7.510^{-6} \mathrm{C}^{-1}\right)$ in the $20-600^{\circ} \mathrm{C}$ temperature range, one can expect to minimize problems of cracks often met during thermal cycles.

In order to get an optimal $10 \% \mathrm{Y}_{2} \mathrm{O}_{3}$ content in the $\mathrm{ZrO}_{2}$ films, the $\mathrm{Y} / \mathrm{Zr}$ ratio in the coating solution was then fixed to 0.15 , according to previous results. Coatings were carried out from $400^{\circ} \mathrm{C}$ to $600^{\circ} \mathrm{C}$, with a $25^{\circ} \mathrm{C}$ temperature increment each time. The relative $\mathrm{Y}_{2} \mathrm{O}_{3}$ content of the films, determined by $\mathrm{X}$-ray microanalysis, increases with the coating temperature as shown on fig. 5. Substrates must be heated up to $530^{\circ} \mathrm{C}$ to reach the desired $\mathrm{Y}_{2} \mathrm{O}_{3}$ content and the two oxides have similar deposition rate when heated to $590^{\circ} \mathrm{C}$. When considering X-ray diffraction patterns (fig. 6), fully stabilized cubic zirconia films are directly obtained when coating temperature reaches $490^{\circ} \mathrm{C}$, where no particular texture is detected. At lower coating temperature, strong peaks are mainly attributed to tetragonal phase (or partially stabilized zirconia) which is in good agreement with the low $\mathrm{Y}_{2} \mathrm{O}_{3} / \mathrm{Zr}_{2}$ ratio detected. In order to better distinguish cubic phase from tetragonal phase, peak broadening was reduced by annealing $\mathrm{Y}_{2} \mathrm{O}_{3}$-doped $\mathrm{ZrO}_{2}$-coated alumina samples at $800^{\circ} \mathrm{C}$ for $20 \mathrm{~h}$ in air. From peak-broadening data, grain sizes have been calculated by a well established method (6). They range from 100 to $300 \AA$ for the highest temperature.

When investigated in cross section by SEM (fig. 7) YSZ films exhibited a columnar grain structure, as already reported by other authors (7-8).

Fig. 5 : Relative $\mathrm{Y}_{2} \mathrm{O}_{3}$ content versus coating temperature

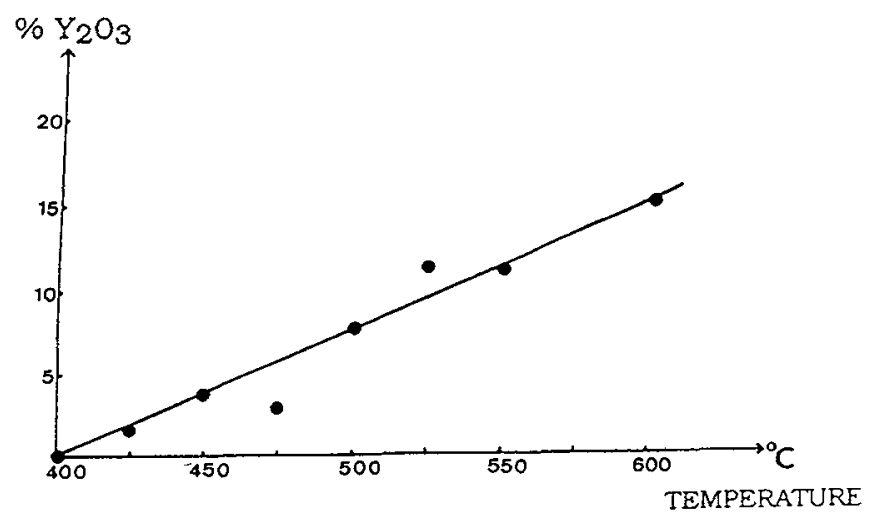



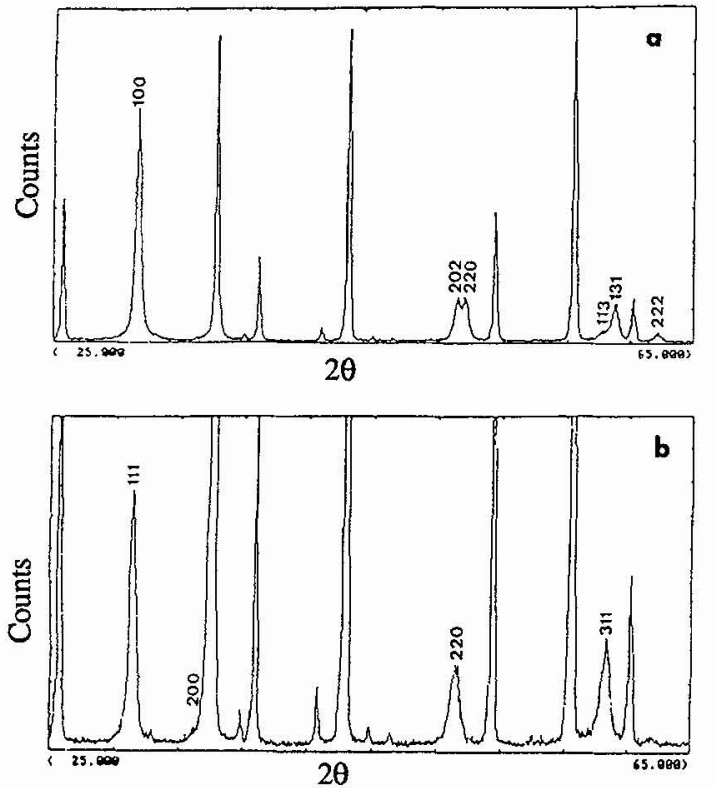

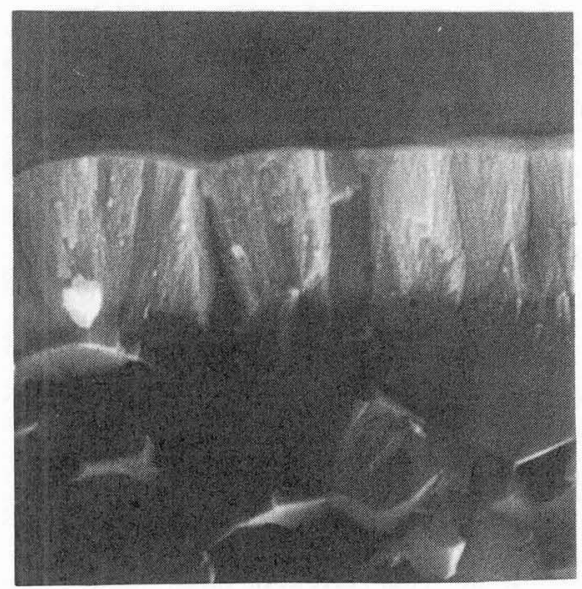

Fig. 7 : SEM fractograph of a 2-um-thick YSZ film

Fig. $6: \mathrm{X}$-ray diffraction patterns of YSZ coated alumina

substrates ; $\mathrm{a}: \mathrm{T}=425^{\circ} \mathrm{C}$, tetragonal phase

$\mathrm{b}: \mathrm{T}=525^{\circ} \mathrm{C}$, cubic phase

\section{3-3 Conclusion}

With a $15 \% \mathrm{Y}$ doping ratio in the coating solution and temperatures up to $500-600^{\circ} \mathrm{C}$, we accomplished the objective of stabilizing $\mathrm{ZrO}_{2}$ thin films in the cubic structure. Average grain size ranges from $200 \AA$ to $300 \AA$ and films are microstructurally dense.

In view of further electrical characterizations, Pyrosol process deposition of electrode materials such as noble metals (Pt, Pd) and electronic conducting oxides (ITO) are being investigated.

\section{YTTRIUM IRON GARNET (YIG)}

Garnet-based thin films are very attractive for magneto-optical information storage or magneto-optical display devices, owing to their high Faraday rotation. Typical methods of preparation for such films, such as RF reactive sputtering or DC magnetron sputtering, involve high vacuum deposition equipments. Owing to its advantages we have used the pyrosol CVD technique for the growth of good quality $\mathrm{Y}_{3} \mathrm{Fe}_{5} \mathrm{O}_{12}$ garnet thin films.

\section{4-1 Experimental procedure}

$\mathrm{Y}(\mathrm{AA})_{3}$ and $\mathrm{Fe}(\mathrm{AA})_{3}$ ( $\mathrm{AA}=$ acetylacetonate) were used as starting materials and dissolved in butanol at $0.03 \mathrm{Mol} / \mathrm{l}$. We used quartz and gadolinium gallium garnet (GGG) single crystal oriented in the direction (111) as substrates. The substrate temperature varied from $520^{\circ} \mathrm{C}$ to $600^{\circ} \mathrm{C}$. The optimum deposition conditions were adapted to the substrates depending on their thickness and thermal conductivity. The deposition rate was greater for $F e(A A)_{3}$ than for $Y(A A)_{3}$ and led to a greater $\mathrm{Fe}$ to $\mathrm{Y}$ ratio in the layer than in the source solution. This ratio was closely related to the substrate 
temperature. For a quartz substrate heated at $540^{\circ} \mathrm{C}$, a $\mathrm{Y}(\mathrm{AA})_{3}$ to $\mathrm{Fe}(\mathrm{AA})_{3}$ ratio of about 4 in the solution led to a pure $\mathrm{Y}_{3} \mathrm{Fe}_{5} 0_{12}$ film. In the case of a GGG substrate heated at $540^{\circ} \mathrm{C}$, a pure $\mathrm{Y}_{3} \mathrm{Fe}_{5} 0_{12}$ film was obtained for a $\mathrm{Y}(\mathrm{AA})_{3}$ to $\mathrm{Fe}(\mathrm{AA})_{3}$ ratio of 6 in the solution. The aerosol flow was typically $120 \mathrm{cc} /$ hour. The deposition rate ranged from 1000 to $2000 \AA$ A hour depending on the experimental conditions. In the case of quartz substrate, cracks were occasionally observed due to the difference between the thermal expansion coefficients of the garnet layer and the substrate. This was never observed in the case of garnet layers deposited on GGG.

\section{4-2 $\underline{\text { Results }}$}

\section{Garnet layers on quartz substrate}

As-deposited layers on quartz were amorphous. After annealing in air at $700^{\circ} \mathrm{C}$ for 3 days, non-textured layers with good crystallinity were obtained [fig. 8].

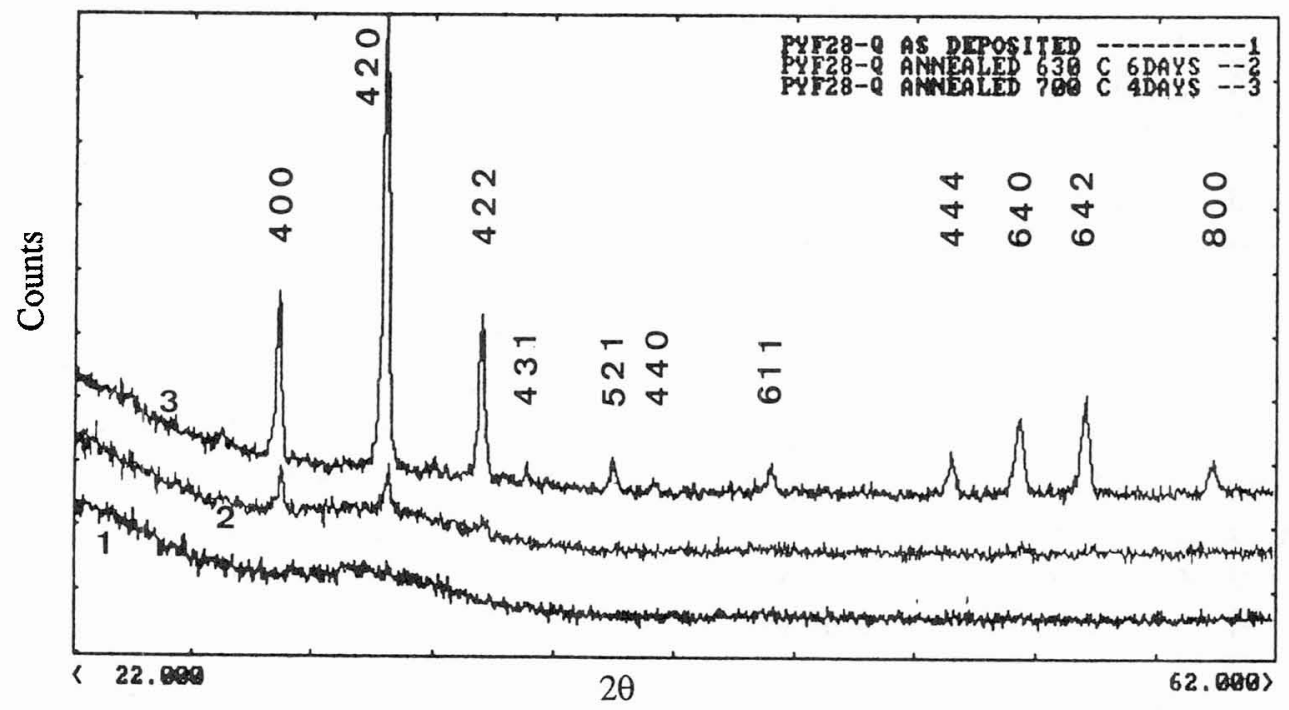

Fig. $8: \mathrm{X}$-ray diffractogram of YIG thin film grown on quartz substrate

The X-ray diffraction revealed only garnet phase reflection lines even when the $\mathrm{Y}(\mathrm{AA})_{3}$ to $\mathrm{Fe}(\mathrm{AA})_{3}$ ratio in the source solution was changed from 3 to 7 . The cubic cell parameter of the gamet phase decreased slightly when decreasing the $\mathrm{Y}(\mathrm{AA})_{3}$ to $\mathrm{Fe}(\mathrm{AA})_{3}$ ratio in the solution. The $\mathrm{YFe} 0_{3}$ phase was observed as well for a $\mathrm{Y}(\mathrm{AA})_{3}$ to $\mathrm{Fe}(\mathrm{AA})_{3}$ ratio higher than 8 when the substrate was heated at $540^{\circ} \mathrm{C}$.

Magnetic properties

The Curie temperature was measured by means of a Faraday balance. The value for a stoichiometric layer was close to the bulk value $\left(\mathrm{Tc}=280^{\circ} \mathrm{C}\right)$, and the transition was clearly defined [fig. 9]. 


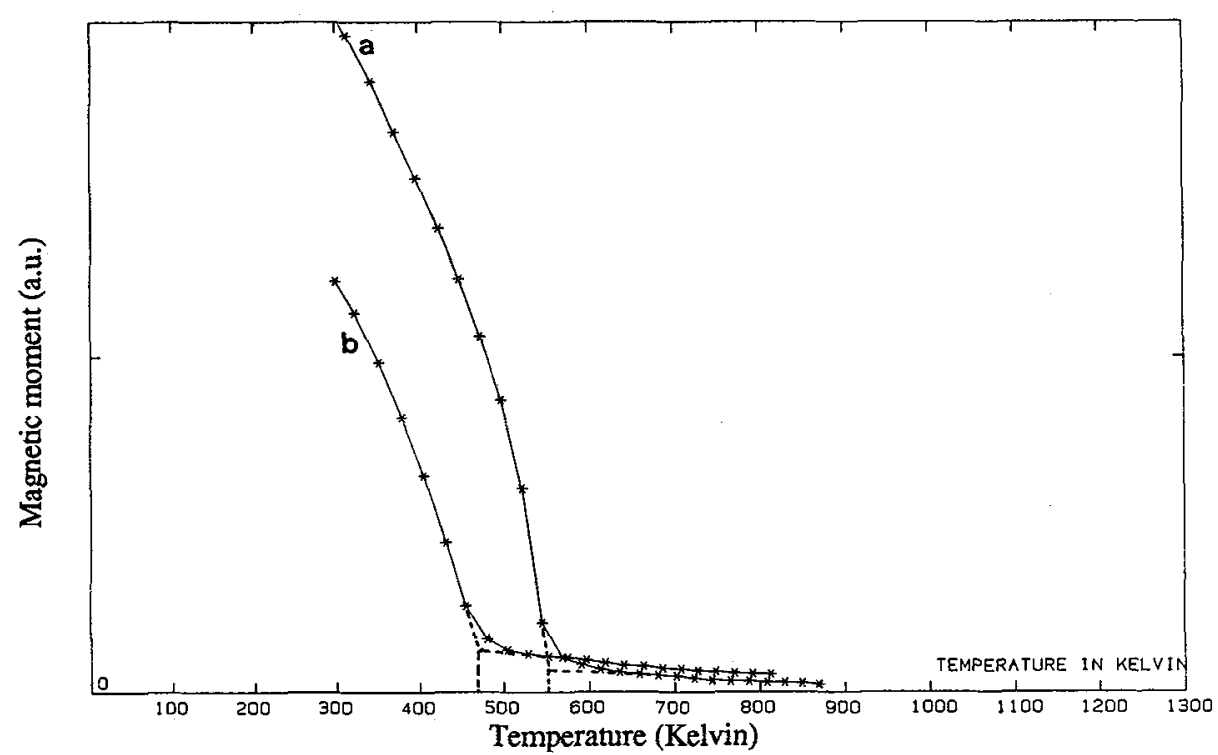

Fig. 9 : Curie transition curve (a) of a pure $\mathrm{Y}_{3} \mathrm{Fe}_{5} \mathrm{O}_{12}$ layer, (b) of a layer with an excess of Ytrium

The layers with an excess of yttrium exhibited a transition around $200^{\circ} \mathrm{C}$. The Faraday rotation measurement was closely related to the layer composition. A pure $\mathrm{Y}_{3} \mathrm{Fe}_{5} \mathrm{O}_{12}$ layer exhibited a rotation of $2900^{\circ} \mathrm{cm}^{-1}$ at a wave length of $514.5 \mathrm{~nm}$ [fig. 10].

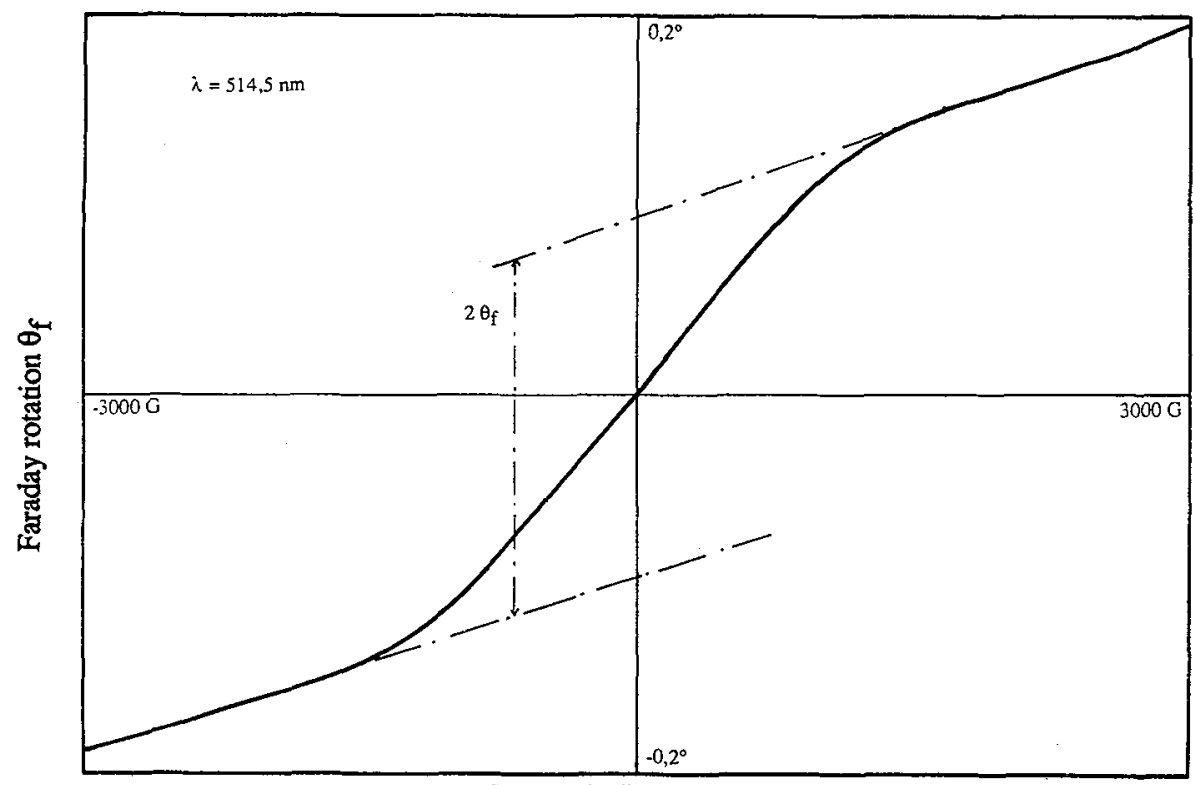

Magnetic field (G)

Fig. 10 : Faraday rotation curve for $3300 \AA$ YIG film deposited on quartz substrate.

The curve has not been corrected for the substrate rotation

A vibrating sample magnetometer was used to measure the film magnetization. The stoichiometric layers exhibited a value of $100 \mathrm{emu} / \mathrm{cc}$, which is slightly smaller than the bulk saturation magnetization value [fig. 11 ]. 


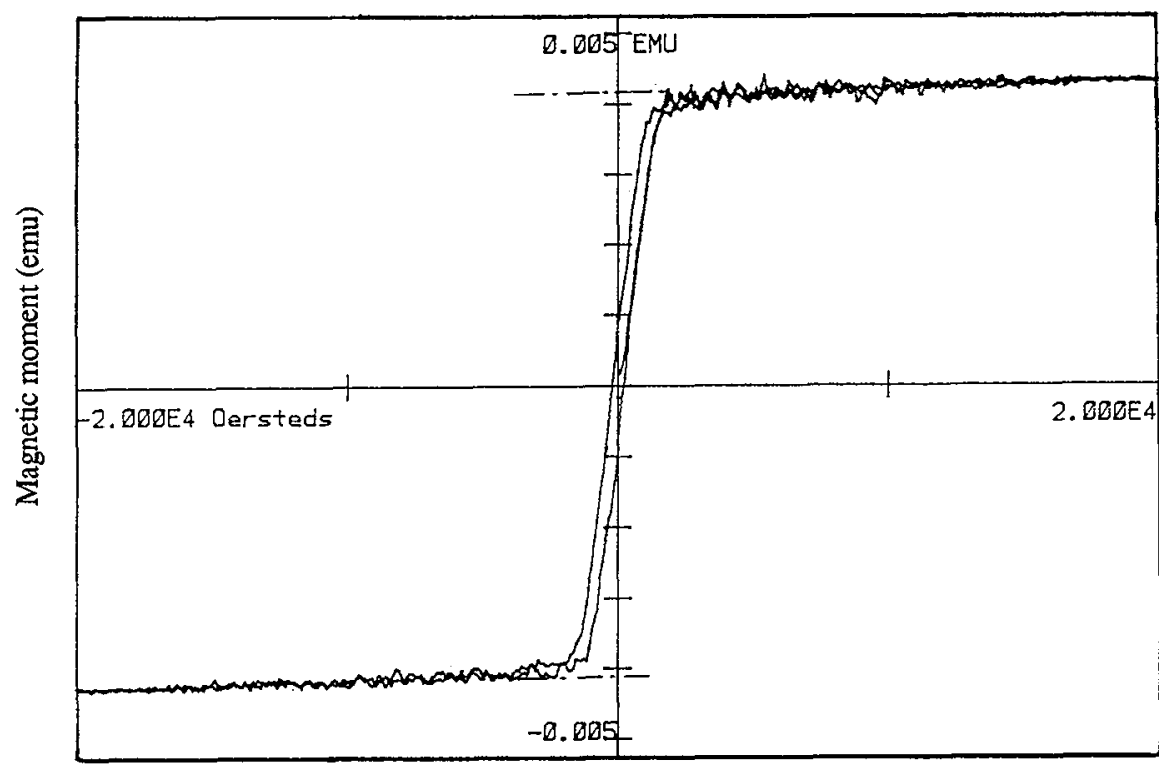

Magnetic field $\left(\mathrm{o}_{\mathrm{e}}\right)$

Fig. 11 : Magnetization curve for $9000 \AA$ YIG film deposited on quartz substrate.

The magnetic field was applied perpendicularly to the film plane

\section{Garnet layers on GGG substrate}

As-deposited layers on GGG exhibited a small Faraday rotation of about $500^{\circ} \mathrm{cm}^{-1}$. Annealing in air at $700^{\circ} \mathrm{C}$ for 3 days led to a value of about $2000^{\circ} \mathrm{cm}^{-1}$ for a wavelength of $547 \mathrm{~nm}$. The X-ray diffraction patterns of these films before and after annealing revealed only the (hhh) diffraction peaks of the GGG substrate. Grazing incidence X-ray diffraction experiments undertaken on annealed layers revealed an epitaxial YIG layer with the [111] direction perpendicular to the surface of the substrate. This epitaxial growth was probably due to an interface reaction between the layer and the (111) single crystal substrate. The (hhh) diffraction lines of the layer could not be differentiated from the substrate diffraction lines by a conventional $\theta-2 \theta \mathrm{X}$-ray diffraction measurement, owing to the small mismatch between the layer and the substrate cubic cell. The magnetization value and Curie point of the textured layers were very close to the values measured for layers deposited on quartz.

\section{4-3 Conclusion}

In summary, the pyrosol CVD technique leads clearly to good quality polycrystalline YIG layers. These layers are not textured when deposited on quartz substrate and appear epitaxialy grown when deposited on GGG single crystal. We are now trying to deposit YIG layers substitued both with bismuth in order to increase the faraday rotation and with gallium in order to decrease the Curie point. Improving these two properties could lead to applications of our layers for magneto-optical recording devices. 


\section{REFERENCES}

1 - J.Spitz and J.C. Viguie, French Patent 2,110,622 (1972) ; U.S. Patent 3,880,112 (1975) ; U.S. Patent 3,890,391 (1974) ; F.R.G. Patent 2,151,809 (1974) ; Japanese 83-845-7 (1971) ; Br. Patent 1,362,803 (1974).

2 - J.W.S. Rayleigh, The Theory of Sound, Vol.2, New-York, 1945, p. 344

3 - V. Lanteri, A.H. Heuer and T.E. Mitchell, "Advances in Ceramics" Vol. 12, p. 119 (1984)

4 - P. Hagenmuller, W. Van Gool in "Solid Electrolytes", published by Academic Press. p. 294-295 (1978)

5- G. Velasco, D. Pribat in "Proceeding of the International Meeting on Chemical Sensors" Bordeaux, July 1986

6- A. Guinier in "Théorie et Technique de la Radiocristallographie" published by DUNOD Paris (1964), p. $462-464$

7 - J.E. Greene and R.E. Klinger, J. Vac. Sci. Technol. Vol. 14, 1, p. 177-180 (1977)

8 - S. Lichter and J. Chen, Phys. Rev. Lett., Vol. 56, 1396 (1986) 